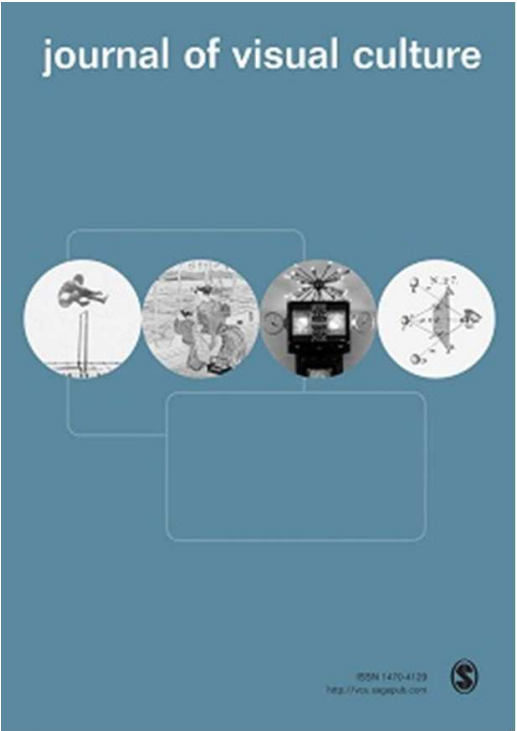

Observance, Notes Towards Decipherability

\begin{tabular}{|r|l|}
\hline Journal: & Journal of Visual Culture \\
\hline Manuscript ID & VCU-18-0008 \\
\hline Manuscript Type: & Original Manuscript \\
\hline Keywords: & Keywords, in, manuscript, attached, here, thanks \\
\hline Abstract: & In manuscript, attached. \\
\hline & \\
\end{tabular}

SCHOLARONE ${ }^{m}$

Manuscripts 


\title{
Observance, Notes Towards Decipherability
}

\begin{abstract}
Provoked by the terrorist-related murders in England that mark the spring and summer of 2017, I have felt compelled to write this article on the idea of observance (observe, care, follow, obey). I engage with this idea in the context of our contemporary Memory Industry - that confluence of memorialisation, remembrance, and commemoration culture; Memory Studies and Trauma Studies; tangible and intangible heritage; digital memory and media archaeology; and its series of facing-backwards-to-go-forwards impulses (the archival impulse, the genealogical impulse, and the archaeological impulse.). Through the Contemporary's prism, I deploy observance as a rejoinder to the seeming irreconcilability between, on the one hand, the incomprehensibility of the Shoah, and, on the other hand, the prevalence of its rendering in figurative and abstract memorials, literature, art, and film; and by way of dark tourism, Shoah selfies, and genealogy websites. I'll propose that because of its assorted senses, as a grievable moment observance may be a way of negotiating (without necessarily wanting or needing to reconcile) such irreconcilability. I'll argue that this is possible because of how observance (observing a minute's silence for instance) as a (secular, vernacular) performative action somehow opens up a space of the imagination that might lead, for good and ill, to a decipherability all the more necessary in our interminable state of exception that is the Contemporary.
\end{abstract}

\section{Key Words}


Observance; grievable moment; memory, remembrance, and commemoration; memorials and memorialization; the Shoah; dark tourism; genealogy websites; Shoah selfies; performative action

\section{Introduction: A Minute's Silence}

It's 10.56 a.m. on Thursday 25th May 2017.

I'm standing outside the Ashmolean Museum of Art and Archaeology in Oxford, the world's first university museum. I'm with a colleague and our students, a cohort of around 20 currently studying on the MA Museums \& Galleries in Education programme. We're on a 'study day' in Oxford, guests of the staff from University of Oxford's Gardens, Libraries \& Museums (GLAM) group; finally an acronym of which to be proud. We have a schedule, with an itinerary that in addition to the Ashmolean includes the Museum of the History of Science, the Museum of Natural History, and the Pitt Rivers Museum.

A museum security guard approaches us. She tells us we need to enter the Ashmolean, and quickly. It's nearly 11 o'clock. It's almost time to observe a minute's silence for the 22 adults and children murdered by a suicide bomber, later identified as 22-year old British Muslim Salman Ramadan Abedi, in Manchester at an Ariana Grande concert on Monday 22nd May 2017.

It's 10.57 a.m.

We're ushered into the Ashmolean's Education Department, and settle in haste. We hear a bell tinkling.

It's 11.00 a.m. 
The minute's silence begins.

Should I keep my eyes open, or close them? I'm never sure - closing one's eyes always struck me as an odd way to observe anything. If I keep them open, where should I look? Anywhere other than down and I might catch someone's eye, and then what: meet their eye? Tear my eyes away? Ignore them? Look right through them, staring off into the distance (which is where both the past and the future, anywhere but the present, seem to reside)? Acknowledge them, with a slightly involuntary grimace, a wince? With stoicism? And how should I look? I really should have my most solemn face on but I can't quite remember how to make it, how it feels from the inside out.

I close my eyes. Head down. I'm solemn enough.

My mind starts to wander...

It's curious that when we close our eyes, we see otherwise. It's brought on, it seems, by a certain inattentive attention, or maybe it's an attentive inattention. It's an odd combination of remembering, speculating, and meandering. It's a daydreaming, an imagining, a visualising. And it's in my mind's

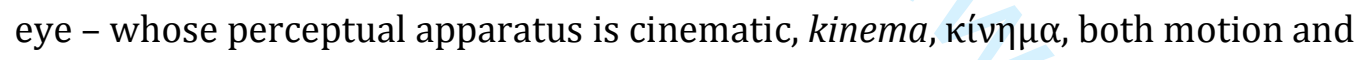
emotion, as ancient Greek etymology tells us - that I picture the scene: the screaming crowd at the concert, the collective panic and confusion; the smell of fear. And it's in my mind's eye that I picture the dead. The never-to-grow-up. The never-to-grow-old. The never-to-be-born. I think about Manchester, and a previous bombing attack there back in 1995 or 1996, around the time of my father's death, at the Arndale Shopping Centre carried out by the IRA. (Might Arndale Centre be an anagram of Ariana Grande, I wonder?) And I remember standing on Oxford Street in '81 or '82, and being shouted at by a panicked 
policeman to 'RUN, JUST FUCKING RUN!' when an IRA bomb was detonated in the Wimpy Bar (whatever happened to Wimpy?), and feeling the boom in my stomach a split second before the whole building's windows blew out. And I glimpse a flash of televisual news footage of the aftermath of the nail bomb in Hyde Park in '82 or '83, and the dead horses, their gargantuan bodies strewn over the tarmac (did any people actually die?). And I recall, after the events of September $11^{\text {th }} 2001$, having to listen to Americans going on and on about how you don't know what it's like having a terrorist attack on your own home soil; and I recall telling them that that's what it was like growing up in London-England in the '70s and ' 80 s. And I cringe at the memory of the suicide bomb attacks on London's tubes and on a double-decker bus (on a double-decker bus for fuck's sake?????) on $7^{\text {th }}$ July 2005 (our very own $7 / 7$ to rival their $9 / 11$; what catchy, handy, strikingly vivid numerical shorthand!) I think about terrorists, terrorism internationally, and about how sick and tired, and sad and fucking furious I am with terrorists, with our War on Terror, and with the almost unremitting (feeling of the) terror of terror. (And I smile at how, in my younger days, in the early to mid '80s I would go on CND rallies to protest over the siting of nuclear missiles in the UK; and how with friends I would steal about in the dead of night daubing 'Barclays fund apartheid' on the bank's storefront in protest at their contribution to the British Empire's complicity in South Africa's white minority regime.) And I ponder imperialism, globalisation and semio-capitalism, democracy and neoliberalism (and I wonder about how liberalism used to be a good thing, and ask myself how it came to be a bad thing; how strange.)

A minute's silence is a mnemonic, I say to myself, a labyrinthine system of memories, sites, and acts. 
All this in the blink of an eye.

I think about Trump with his small hands, and Brexit; and how I'm still in denial about that fiasco. And I wonder what the future now holds (and what it no longer holds) for my daughter, who is a British citizen, and I can see why her mother is pushing so hard to get her an Italian passport. Which reminds me, my daughter's school sent us an email this morning, telling us that they were going to be observing a minute's silence for those murdered by the suicide bomber in Manchester. And I speculate about what my daughter's form teacher... I must ask her... is telling my daughter right now...I must ask her too... and her classmates about what it is to observe a minute's silence: what is a minute's silence? What happens in that minute? What's it for? Who's it for? And what does it actually mean for it to be for those murdered? How should my daughter and her classmates behave? How should they use the time? Should they fill it, and, if so, how should they fill it, and with what? My daughter is only five and three quarters; how can she possibly comprehend any of this? And I wonder what my daughter is actually thinking right now.

A minute's silence is a grievable moment. As a grievable moment, in that one minute's silence hundreds of lucid and poor images rolodex by; it's a musée imaginaire taking shape. Profound and paltry thoughts in equal measure come and go. Feelings so heart-wrenching and so self-indulgent. Found memories, fragments of memories, screen memories, stray words and phrases, evidence and conjecture, all pouring into my mind's eye from goodness knows where, 
arranging and re-arranging themselves without necessarily logical connections. These are the shapes, the directions, the trickling streams (the percolating, as Michel Serres might put it [1995[1990], passim]) of my consciousness. It's not random; it's a patterning.

This grievable moment is my minute's silence, from 11.00 a.m. to 11.01 a.m. on Thursday 25th May 2017. I, you, one, we observe a minute's silence like this or like that. I have had many others, and I'm afraid I know that there will be many more to come.

As a grievable moment, what and how is a minute's silence?

As a ritual, a minute's silence is observed to mourn, remember, and commemorate the dead; it is a keeping watch over them. It is a ceremony to think and reflect, to be together - in our difference - in solidarity. It is a gesture of respect, and, respectfully, it is performative act that is generative of thought, utterances, debate, argumentation; it is a demonstrating.

What incident, though, 'gets' to count? Who 'gets' the silence? On what grounds? How is it formalised? Who decides?

A minute's silence is observed, and it is also held. But how do we hold it (as if it were a thing): Lovingly, touchingly, tightly, carefully, at arm's length?

A minute's silence is scheduled to take a minute. (What kind of taking is this - is it borrowed, loaned, purloined? And from where? And from whom?) And with all these minute's silences, sometimes two, three, or even four or five minute's silences - don't think there aren't those who baulk at this 'silence 
inflation' - how much time have we banked, individually and collectively, and what might we do with it, how might we spend it, what might we spend it on?

A minute is sanctioned for this silence, is given to it, is given over to it, but such an apportioning is a red herring, a logical fallacy, a mere device. Like time itself. Because the minute in a one-minute's silence is not under the tyrannical rule of Chronos; we are not subjects of and subject to such metering and measuring and managing. Or, rather, perhaps as a hyper-minute, the most minuted minute, in which each second is felt, more so than in the previous or successive minutes, it circumvents such managing. Either way, a one minute's silence as a time of and for observance, as a grievable moment, is instantaneous and goes on forever; it is a stretching, like daydreaming, imagining, visualising. This minute's silence is chrono-logical time yielding to the kairological.

A conjuncture between structure (rituals instituted, conventions prescribed, operations enacted) and contingency, as a performative action this minute's silence is always and already a right or opportune moment, a moment of time lapse, a moment of indeterminate time, an interruption of time, immanence, an intervention in time, time unleashed, released, set free, in which we as temporal beings might intervene to transform circumstances. It's not so much a matter of time per se as it is the matter of timing, and in particular the right timing; and that such timing necessitates human intervention. (Chan, 2010).

As a grievable moment, a minute's silence embodies and articulates such a combination of remembering, speculating, and meandering; and immanence. In this grievable moment, this one-minute's silence, in my mind's eye, I see my father. Horatio, methinks I see my father. My long dead father. And I see, 
for a split second, his parent's families, the majority of whom were murdered by the Nazis in the Shoah.

\section{Observing, Caring, Following, Obeying}

Observance is, etymology dictates, from the French (observance) and the Latin (observantia). Because of how I want to use observance in this article - I have no interest in, use for, or truck with its religious filiation - I present its etymology thus: From the Anglo-Norman and Old French observance is the action of observing a religious rule, religious rule, religious order observing a rule, rule of a religious order, respect, and action of observing. From the classical Latin observantia is keeping or following of a law or custom, attention, respect, reverence, notice, in post-classical Latin also observance of divine law, religious rites, rule of a religious order, rule of the Franciscans. ${ }^{\mathrm{i}}$

For my purposes here, the Oxford English Dictionary shows explanatory origins that enable us to comprehend observance as (1) the action of observing, noticing, or paying attention to what is said or done (2) attentive care (appearing in Chaucer, Shakespeare, and elsewhere) (3) the act or practice of following or respecting a particular law or of fulfilling a duty, etc.; adherence or due regard to a particular custom, practice, principle, etc. (4) an action performed in accordance with (and conforming to, obeying) prescribed usage; a customary action, ceremony, or ritual; a custom; an act performed in accordance with social convention; formerly a necessary or obligatory action, practice, etc.

Despite my disinterest in observance's religious filiation, I do have an interest in what a more secular or perhaps vernacular observance - as a word, 
an act, a performative action, a moment to intervene - might look like, what it might be, and what, as a grievable moment, it might have the capacity to $d o$; as impossible as it is, I know, to untether fully (or even perhaps sufficiently) this word, and its meanings and its usage, from its theological moorings.

Etymology makes such intervening conceivable though because observance is always and already a performative action: it is the action of observing, attentive care, the practice of following a particular custom, an action performed in accordance with a ritual. Moreover, observantia and observatio, both diverbal substantives from observo, intimates that to observe isn't always to obey, and that to always obey may well be to fail to observe matters of significance.

\section{The Shoah, Memory, and Memorialisation}

\section{$\underline{\text { It's All My Father's Fault }}$}

I've been writing a book about my father, long dead. It's a book partly about memoir, biography, and autobiography as forms. It's also a book partly about research itself as a praxis (re-searching, searching, finding, not finding, and what to do about all this.) Finally, it's an actual biography of my father (his PolishJewish émigré parents; his Communist leanings as a Jewish boy brought up in 1920s and 1930s east London; his anti-fascist acts; his Jewishness or lack of it; his trade with the Soviet Union in the 1950s and 1960s; his hosting of fundraisers for individuals affected by McCarthyism as well as for Communist 
organizations internationally; his spying for either the KGB or MI5 or both; his bankruptcy; his radiance as a man and his failings as a father).

So, I'm writing this book, but currently I'm stuck.ii I'm researching and writing the chapter about the murder by the Nazis of the majority of my father's parent's families in the Shoah. The chapter centres on a photograph that marks the visit he and his parents made to their families in Poland in 1936 or 1937, to try to persuade them to come back to London. They didn't come back. The photograph may have been taken in Chmielnik, where my father's father's family came from, or the Lublin/Lukow area, where my father's mother's family came from, or Warsaw, where one or other or both families may or may not have moved to by the 1880 s or by the mid-1930s. I know nothing about any of the individuals in the photograph. Nothing. About any of them. (Other than my father, and his parents, of course.)

There is scant information on my father's family, or on my father actually - no diaries, no notebooks, no unpublished memoir, and no family archive, nothing but a few photographs, a small cardboard box of his belongings, inexact memories, half-remembered stories, anecdotes, and the past as an image that flashes up fragments that force their way into consciousness.

So I sit in the British Library, reading and crying. Because to supplement such a skeletal family archive, I've read scores of Shoah survivor autobiographies and memoirs; survivor and victim diaries and journals and collections of notebooks, these notes towards histories of the present written for the future; and the records of the death-camp Sonderkommandos; evidence given at the Nuremberg trials on the Auschwitz extermination camp (and other such evidence); hundreds of books and articles by academics and researchers; and 
listened to hours and hours of recorded oral testimony. Not to mention my nonBritish Library-related research activities: watching documentaries and movies, and searching genealogy websites for information on my dead father's dead family.

It turns out that you can't dip your toe in the Shoah; it's not a subject you wander around blithely. I know that now, and for sure I know I've bitten off more than I can chew. So as I conduct research for the chapter of the book on my father on what is surely one of the most delicate academic subjects of all time, I'm doing whatever I can to try to cover my arse, to make sure my unfamiliarity doesn't come back to bite me; which it inevitably will.

My own misgivings notwithstanding, even though it might be too soon, I feel the need to enunciate. This is provoked by three musings: (a) my thinking about my thinking about the one minute's silence on Thursday $25^{\text {th }}$ May 2017 as a grievable moment; (b) feeling emboldened by the idea of observance (observe, care, follow, obey) as an act, a performative action, a moment to intervene, a doing; and (c) being urged on by what it means to do research on/think the Shoah at this historical conjuncture which to me seems to have become an interminable state of exception in which the Contemporary's present-ism museumifies the past, history, to sell it on at a profit, and in so doing colonises the future to mitigate its risk.

\section{To Destroy the Evidence}

Against the present Memory Industry's ahistorical attitude, ${ }^{\text {iii }}$ some of what I've learnt so far is this: 
The Shoah is a perfectly calibrated calamitous union of dispassionate bureaucracy and de-individualising malice. On the one hand, with its modern bureaucracy and technological imperative, as many have argued the Nazis utilised the principles of instrumental rationality to stage industrialised mass killing. The destruction of European Jewry was a textbook 'administrative process'. (Hilberg, 1961, 9) The Final Solution to the Jewish Question (die Endlösung der Jugenfrage, Endlösung for short, codified at the Wannsee Conference on $20^{\text {th }}$ January 1942) may have been either determined by or an outcome of Nazi bureaucratic culture. (And, like so much bureaucracy, what starts out as a means to an end becomes an end in itself.) But either way, as a death factory the Shoah was a technocratic operation in efficiency seeking optimum solutions to exterminate the Jews. On the other hand, is its deindividualising malice; because of course such 'machinery of destruction' doesn't have its own volition. (Hilberg, passim) It was powered by a racist ideology of 'redemptive antisemitism' (Friedlander (1997[1988]), and manned by vicious, brutal, ruthless, super-ego-charged, antisemitic individuals who wanted to wipe the Jews off the face of the earth.

The intent of such Nazi bloodlust - which is what makes the Shoah genocide not 'simply' a crime against humanity - was to wipe out each individual Jew, one by one, and 'the Jews' en masse. To wipe them off the face of the earth, and also from the earth itself (to de-contaminate the polluted Nazi-occupied soil), and to extricate them from individual and collective memory. To eradicate them so that it is like that they never existed. So that there is no corpus - no body to claim, no bones to bury, no ash to inhume; they must be obliterated at the atomic level. To be disappeared. Completely. No corpus, no body, but also no 
body of writings nor texts, no language nor speech, no religion nor law nor ethics, no culture nor identity nor cuisine, no everyday practices nor infraordinary observances. So that there is no body to remember; and so no body to mourn.

And nobody to remember. Because if there is no one left to mourn, there is no more memory. To 'destroy the evidence', as Primo Levi puts it in The Drowned and the Saved, (Levi, 2003[1986], 1) is to destroy memory, which is to destroy the past, yes, but it is also to destroy the possibility of memory into the future, and thus the possibility of the future per se. Memory deletion is not sufficient; only memory destruction will do. Which is why the Nazis were also so intent on destroying Jewish synagogues, cemeteries, and gravestones: if there is no one left to mourn, and no place left to mourn, there is no future as such. (Young, 1993, 189).

Indecipherability

Against our Memory Industry's complicity in 'the obscenity of the project of understanding' (Lanzmann, 1995, 207), I would want to affirm that the Shoah is a calamity beyond comprehension; it is a failure to understand.

As an event it exceeds our capacity as human beings to apprehend, to get it. Again and again it is described as inexplicable, unintelligible, unspeakable. So incommensurate is it that, commentators have proposed, we should not empathise even, because we cannot empathise, with an experience of survivors and victims so beyond our grasp. 
It exceeds the limit of the bearable, of what is capable of being endured. For us the Shoah must remain in- or un-comprehensible. It is forever un- or nonimaginable. Eternally ineffable. It is described, rightly, as un-describable. It exceeds the limits of language. It defies language. Words are insufficient; these words are insufficient. It exposes crudely the insufficiency of words as such.

It exceeds the limits of representation. It is inexpressible and unrepresentable. Representation itself is found wanting.

It exceeds the limits of form, of all forms, whether figurative or abstract, of form as communicable, of communicable form.

For the Shoah is an anacoluthon, a sentence (or construction) whose grammar collapses; it is a logical incoherence of thought, a discontinuity, a not following on from.

It has an in-communicability about it.

Some would say that this calls for silence.iv

Others would say that the Shoah is beyond comprehension, and that as incomprehensible, because of its incomprehensibility, we must struggle to decipher it, in its incomprehensibility. Levi uses this verb, to decipher (decifrare), in his attempts to explain the Shoah's inexplicability and thus the need to decipher it.

To choose not to speak, to be silent, to refuse to communicate - and here I am with Levi again - is to peddle in ambiguity. One can and must communicate, he writes. (Levi, 2003[1986], 68, 69).

This is a necessity; it is also an injunction. There is an ancient Jewish injunction to remember; as there is an injunction to name the dead, to honour them, and give them a proper burial. 
One must struggle, then, to decipher the un- or in-decipherable. One must find words (a language) to articulate the unspeakable; to find forms to forge a bridge to the unintelligible and the inexplicable; to render the un-representable; to mould from the ashes and bone fragments and gold fillings words and forms that can be fabricated into social hieroglyphs that are decipherable, even if we always already know that such words and forms are insufficient.

Why? Because we have to remember. And because this remembering, which is a mourning and a commemorating both, can take place by way of words and forms, even if they are insufficient, which they are.

'To write poetry after Auschwitz is barbaric', pronounces Theodor Adorno in 1951, which has always for me been a demand to struggle under these exact conditions to do so. (Adorno, 1997[1951], 34).

You can't bridge the abyss, to paraphrase filmmaker Claude Lanzmann, (Lanzmann, 1995, 204, 206) and yet I'd argue you must try to find the words and the forms to articulate the impossibility of articulating it. Because what there are, are words and forms that describe and render how there are no words and how there are no forms to describe and render the Shoah. And while such words and forms will always only ever be a proxy, always ever only an approximation, they are at least that. This is the paradox or double bind in which we find ourselves.

\section{The Unmarked}

How, then, to mark the unmarked?

The injunction to remember, and to historicize - always historicize demands the sheer abundance of words (of poetry, of literature, of 
autobiography and memoir, of research and academic studies), of images (photographs, drawings, documentaries, movies), of things and objects, of memorials and monuments and museums. Because we need to remember, we need to need to remember, and we can't remember in a vacuum, especially if we have no memory from which to draw. And, because of this obligation to remember, despite and because of its complexity, such an obligation needs to be honoured.

That said, such a demand has led to words and images and environments many of which, for me, are found wanting because they do not carry with them this a priori knowledge that they are insufficient, proxies, that there are no words and there are no forms to describe and render the Shoah.

Nonetheless they all serve a purpose as memorials around which our remembering (if not our memories) might congregate. ${ }^{v}$ In this regard, memorials (I am referring to all of these words and images and environments as memorials; as structures-to-remind-us) are perhaps best understood as operative words and operative images and operative environments (to use and extend filmmaker Harun Farocki's term 'operative images') that 'do not represent... but rather are part of an operation'. (Farocki, 2004, 17) For, they are sites for the mediating and re-mediating of memory; they are shaped by and shape memory itself. They are a mnemonic, and to this extent they collectively form a post-fact Shoah archive for the future. It is around and by way of such memorial forms, by which memory is constituted for the purposes of mourning and remembering and commemorating, that narrative, however fragmentary, might emerge. It is around them, as them, that extermination camps, concentration camps, ghettos, 
killing sites, archives, museums, and many individuals might begin a process of memory-telling.

Already in the 1940s, along with the first memorials to the Shoah period (the Yizkor Bikher or 'memorial books') came the first of hundreds and now thousands of memorials. Early sculptural memorials were in the tradition of funerary monuments and war memorials (towers, stelae, and so forth), and included figurative sculptures, often in the 'heroic' socialist realism traditions, depicting and celebrating the human spirit, acts of heroism, and the fallen. But soon enough Shoah memorials become more abstract, more in line with avantgarde sculptural traditions, and from the 1960s onwards, whether as abstracted figurative forms or abstract forms per se, this has persisted as the most customary Shoah memorial form. This is absolutely because of the Shoah's abstract nature, which is to say that abstraction attends to both the need to represent and to remember, and also because abstract form lends itself to the abstract thinking necessary for rendering the barbaric violence of history arrested, the devastation of lives cut short, the shattering of hope and the ruination of the future, and the indescribability of the Shoah as it pertains to individuals, in its particularity, and in its enormity.

In all cases, with abstract form, it seems that the fragment is the unit, the building block for the possibility of operative re-assembling (of history, lives, hope, the future itself), much as one knows that such a re-assembling is insufficient. 
To mark the unmarked is the de facto operation of memorials as structures-toremind-us at the two predominant types of Shoah sites: on-site 'sacred' places and off-site secular places.

On-site sacred places name the place, the peoples, the individuals: extermination camps, concentration camps, ghettos, death marches, and the killing sites where mass shootings took place. They are sites of mass death, or of an individual death, and are haunted by the ghosts of the unmarked multitude Auschwitz, Belzec, Sobibor, Treblinka, and so on.

Memorials at off-site non-sacred places - museums, monuments, public statues, archival resources, etc. - in the interests of remembering sever, or deracinate even, the affect of proximity from proximity itself, and, in re-siting it as a 'Holocaust effect', (van Alphen, 1997, passim) do violence to such sacredness even as they look to heal a wound (what Levi calls 'the old trauma, the scar of remembrance') that demands to remain raw. (Levi, 2003[1986], 185)

Memorials at sacred and non-sacred sites, but more saliently sacred and non-sacred sites as memorials, do though mark the unmarked. In their own ways, as insufficient as they are, if and when they carry this knowledge with them palpably, they mark real murder and abstract murder; since the death at the extermination camps, but also elsewhere, is always figured as both literal and figurative, referential and metaphorical or symbolic. It's because of this that they can be places of reflection and learning; of remembering and commemorating; of comfort, sentimentality, and affect; of claustrophobia and kitsch; public and 
private, collective to the point of generality, particular to the point of overidentification. They let in the light bathing us in an ethereal glow, and they block it out, casting us out into a shadow hinterland. They are sympathy machines, and as sites of memory operation, with their tropes of modern memorialising, by 'arrest[ing] the past as past' they can both mark the unmarked and expose the profound dangers of monumentalisation as tantamount to forgetting which is, ironically, a decisive feature of the Memory Industry. (Young, 1993, ???)

\section{The Memory Industry: Dark Tourism, Shoah Selfies, and Genealogy Websites}

In our Memory Industry, especially as it vectors with the leisure or 'experience economy', the resonance of such site-specific and site-responsive memory-telling spotlights three troubling features that are, perhaps, a consequence of our dealing with sacred places in secular ways. They are all of a new-ish commemorative order: the pre-Internet phenomenon of dark tourism, the postInternet trope of 'selfies at Auschwitz', and genealogy websites which, surprisingly, may turn out to be the most odious of them all.

Any visit to Shoah sites, whether sacred or non-sacred places, is always and already dark tourism. ${ }^{\text {vi }}$ Such dark tourism (including Shoah tourism, more generally referred to as Holocaust Tourism - lest we forget, Auschwitz is Poland's most popular 'tourist attraction') is troubling because it is never not fraught and irresolvably contradictory edu-tainment. On a good day, for good or ill such tourism encourages historical understanding and self-knowing, enables us to learn the lessons of the past, confront our mortality, letting us pay our 
respects, remember and mourn, satisfy our need and our curiosity, do penance, clean our conscience, and assuage our guilt. On a bad day, such sites as touristic form commodify our humanity beyond compare, turn death and suffering into commercialized consumables, monetize memory, exploit what we have left of our empatheia for gain (this is what Disneyfication really means), and prompt us to luxuriate in our morbid wanderlust. (Usually it's an admixture of the two.) Such contradictions are captured rather well in Ukrainian filmmaker Sergei Loznitsa's documentary 'Austerlitz' (2016), a study of dark tourism, or, better, 'dark tourists' at Nazi concentration and extermination camps including Dachau and Sachsenhausen, screened recently at Tate Modern and elsewhere internationally. (Figs. 1, 2, 3)

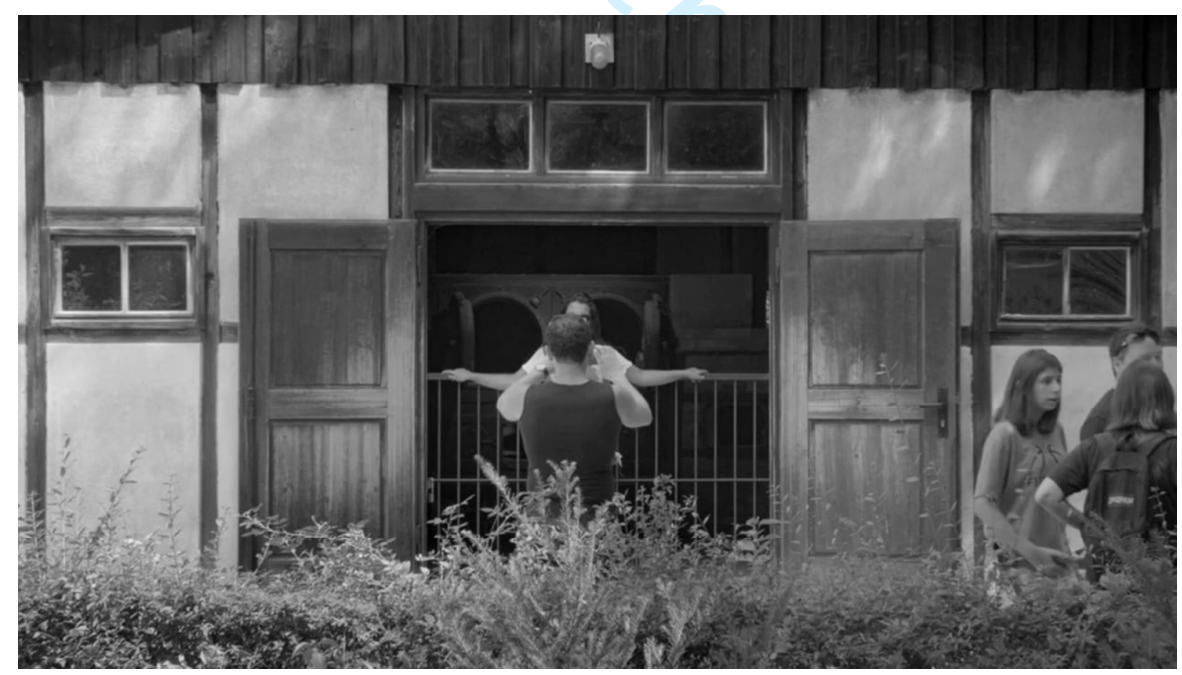



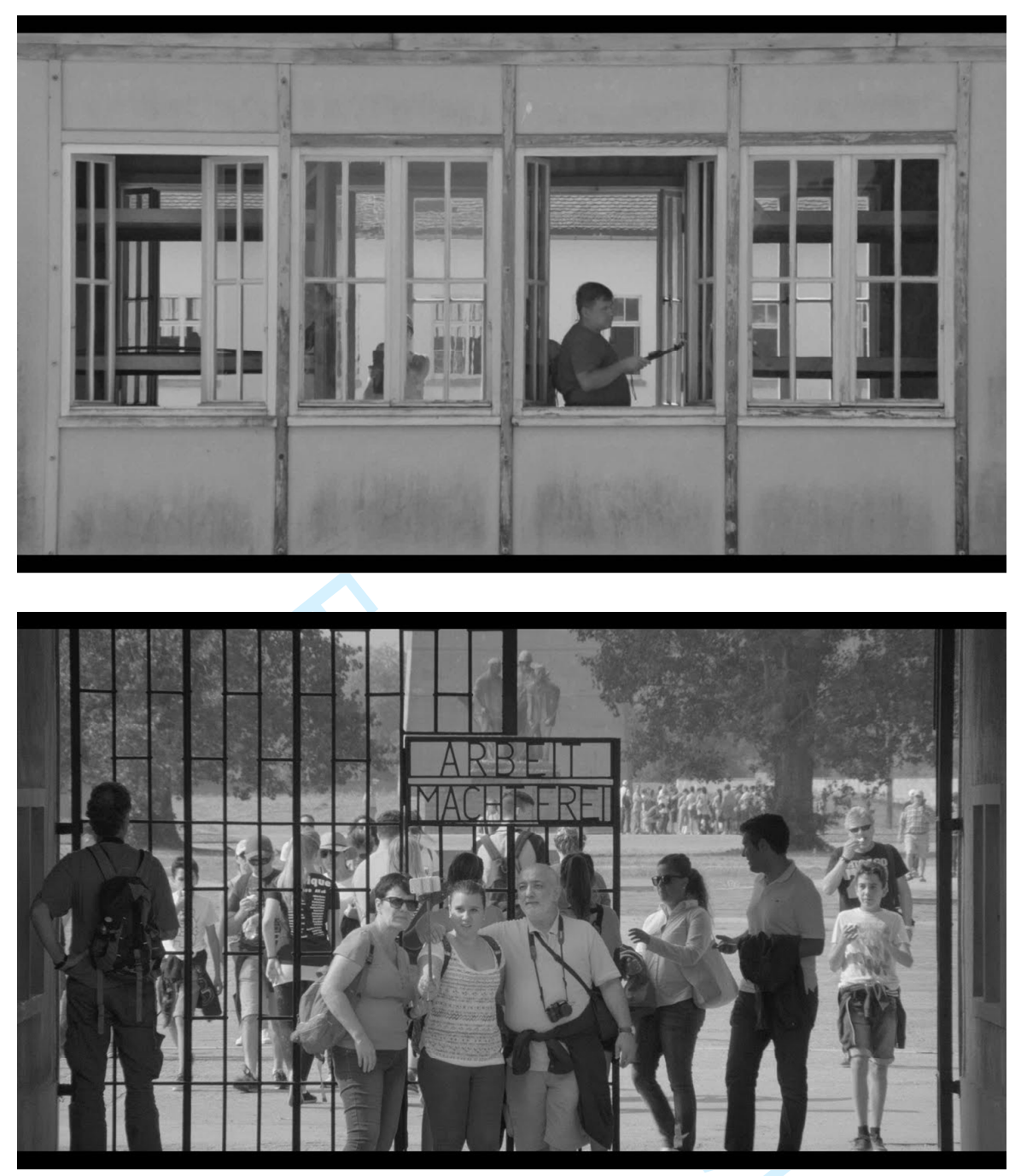

Employing some of the sensibility deployed by photographers Martin Parr in 'Small World' (1995) (which is still unsurpassed in its absurdist and biting vision of the joylessness of touristic banalities) and Paul Antick in 'itourist? Journeys through the Holocaust' (2006-07) (which is still unsurpassed in its photographs of dark tourists assuming the stylized poses of the iconographic blankness of fashion advertising) (Fig. 4), the documentary is an observing, you might say, without commentary, using a hidden camera to show tourists taking photographs and selfies and listening to audio-guides, mediating and remediating their experience of site, history, remembering, and observing itself.vii 


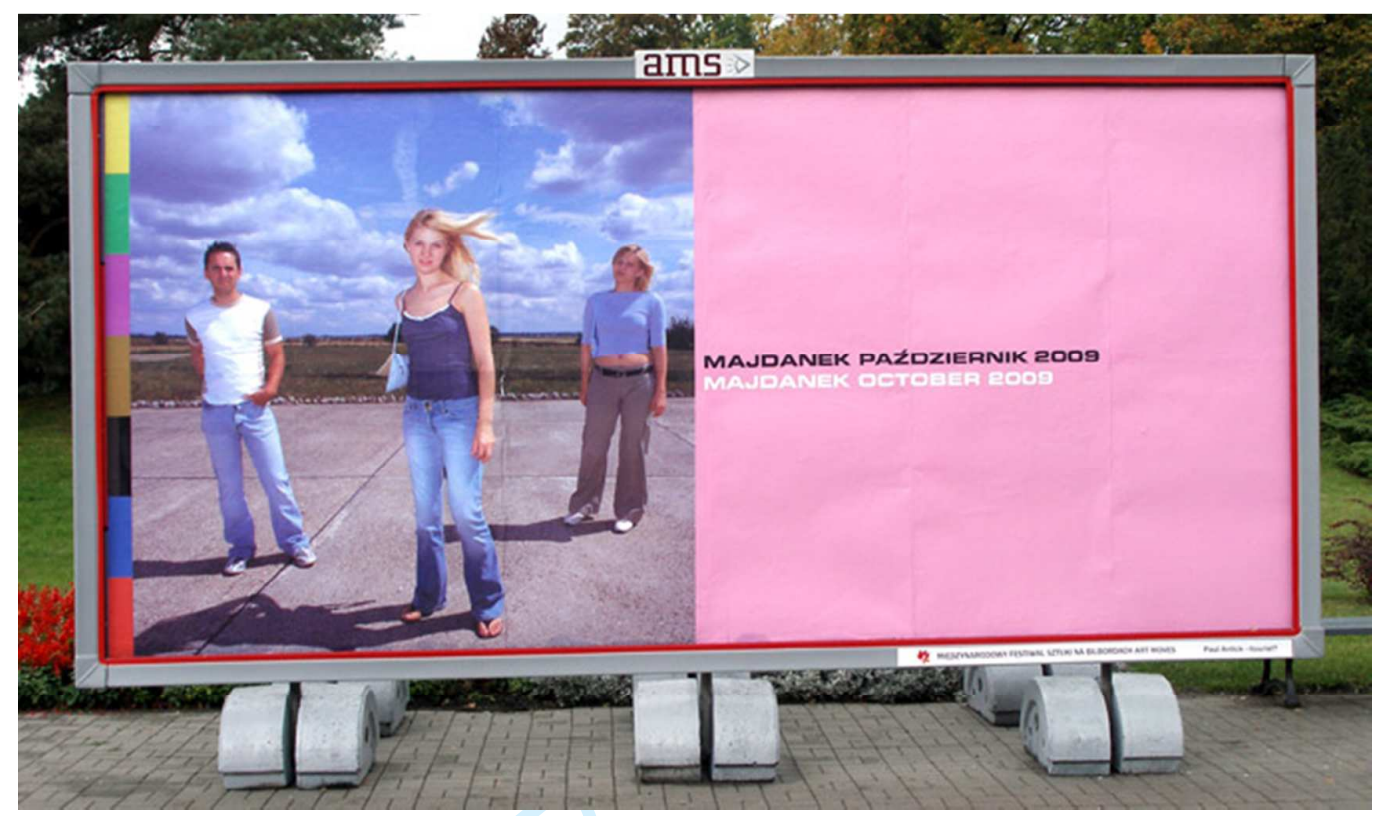

They wander, they stop, they stare; they stare at things and they stare through things; they look confused, bewildered, lost or bored, with glazed gazes, and then they take a photograph, and snapping a snap seems to make them feel better. It's comforting and satisfying like they've accomplished something - done their duty, endured - like their conspicuous compassion has been affirmed and confirmed. This is how the documentary draws our attention to what we already know: performing (rather than performative) observance is unreflexive obedience, a passive engagement that, by way of a preservationist impulse, turns history as materialist concept into heritage artifice.

The Memory Industry's second troubling feature is that in the Age of the Selfie dark tourists are engendered to document themselves posing at Shoah sites by way of photographic self-portraits. Here I am, giving a thumbs-up at the Memorial to the Murdered Jews of Europe in Berlin. (Fig. 5) Here I am, cuddling at the main entrance gateway to the Auschwitz camp. (Fig. 6) 

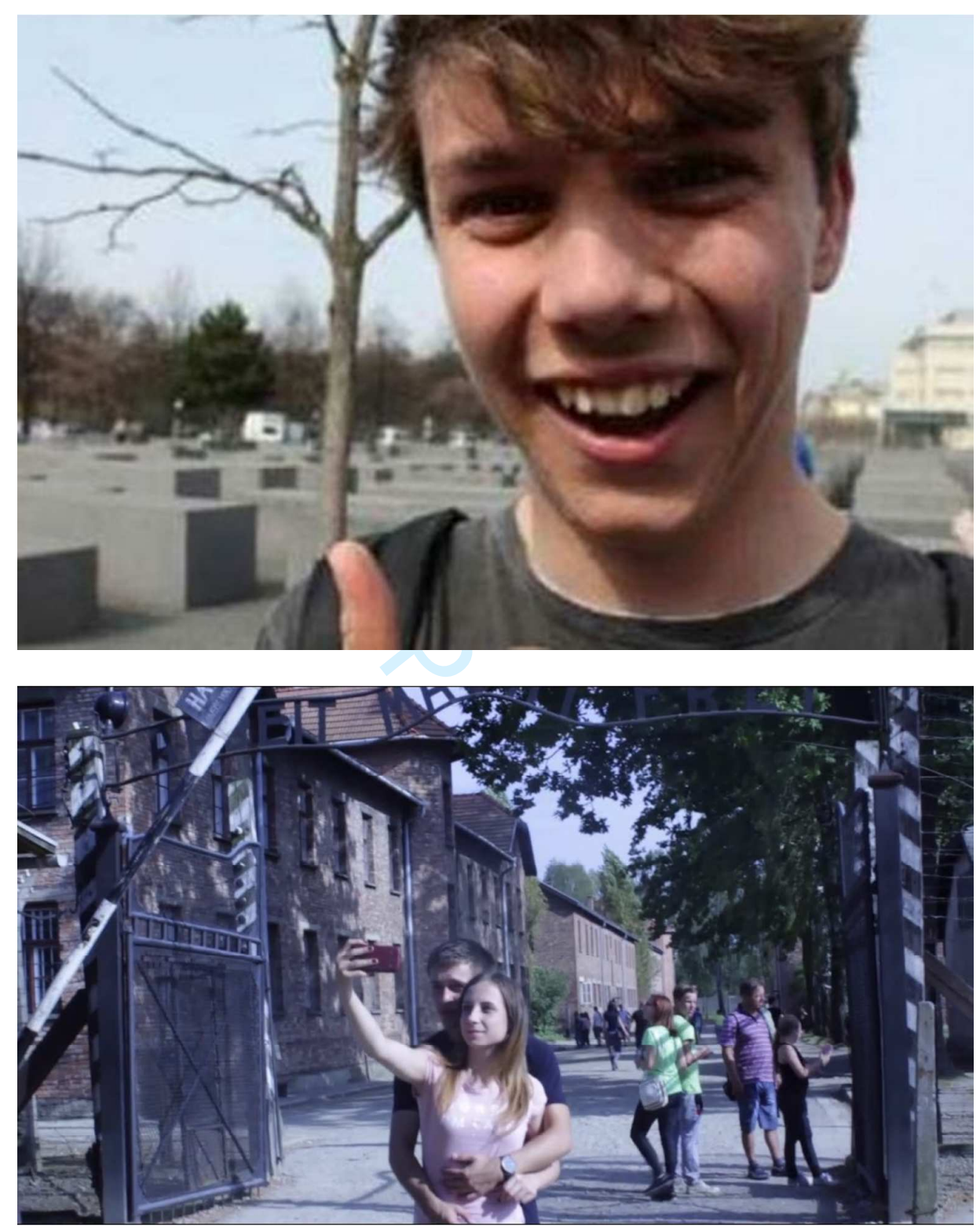

These self-portraits are then posted on Facebook and Instagram, but also on geosocial networking mobile apps Tinder and Grindr. There has been much shrillness around these ritual selfie acts as disrespectful and inappropriate, as evidence of the ignorance of tourists, of youthful stupidity, the vacuity of narcissistic irony. The moral backlash is well under way, with 'shaming' the most prevalent rejoinder: the journalist Jason Feifer's Selfies at Serious Places tumblr 
blog re-posts them; and Berlin-based Israeli artist Shahak Shapira's 'Yolocaust' series (http://yolocaust.de) photoshops them into archive footage of the Shoah. In spite of this, perhaps because of it, I might dare to argue that if dark tourism is generally a passive or docile engagement, in this specific instance, taking a selfie at a Shoah site is an active or willful disengagement, and that as a performative action of non-observance it is institutive. Whether they know it or not, whether they care or they don't, they're dis-obeying. They're breaking the (etymological, but even more so the moral) stranglehold of the obligation, the rule that obliges us to observe, to care, to follow, and to obey. Given that observance exerts a formidable collective pressure to obey, this dis-obeying is a refusal to be obliged, and refusals that flout the rule of law are always interesting. viii

(These selfie-portraitists are also, incidentally, disobeying the rules of injurious looking that are woven into the fabric of the tourist gaze: they don't stare $a t$, they don't gawk, or rubberneck, or seek out a so-called authentic Shoah memorial experience; they just look at themselves looking at themselves in an infinite regress. And are delighted if slightly embarrassed by this self-beholding.)

Passive engagement is supplanted by active (even if it's not willful) disengagement. Such passivity is supplanted by active disinterest as disobedience. Willfully disrespectful and inappropriate acts, whether born of ignorance or impropriety, even if it is merely incidental dis-obedience, at a minimum such dis-obeying foregrounds how the Memory Industry disappears the profound challenges of critical thinking, the traumas of history, and the obligation to remember, thereby pushing them to the fore. I'll take such acts of active disengagement and disinterest over passive engagement almost every 
time; and let's be reminded that no one ever claimed that performative action is always intrinsically for the good.

The third feature of this new-ish commemorative order is for me the most disturbing, strangely: the advent in our Memory Industry of online genealogy sites. They are the new memorial sites of pilgrimage for The Genealogy Generation. They are new regimes of remembrance and commemoration, new modes of storing and gathering and transmitting the past, for our reasonably new, hugely popular and populist preoccupation with personal history. These websites have become custodians, caretakers, archivists of memory globally, including of the Shoah. They are the new memorials to the dead. Like memorials before them, they are 'memory spaces' offering a 'surrogate experience', (Young, 1993,285 ) but it is an experience that is doubly displaced and thus doubly disturbing: for the genealogy tourist, history as materialist concept becomes heritage artifice and place in its singularity becomes non-place (aka my or anyone else's office or living room or study or bedroom). It is the benign benefits of these online genealogy sites that for me are, perhaps somewhat counterintuitively, the reasons why they're now at the forefront of dark tourism praxis:

(a) These web-based archival sources and resources are plentiful, convenient, available, and easy to access. This is what it means to do genealogical research in the age of the Internet - for the armchair genealogist, it's a dream come true. Quickly, too quickly, a search results in an abundance of Shoahrelated websites, online databases, and aggregating databases, collections, and documents. Such searchable databases are search-able to an unprecedented degree. A record, a document, a Page of Testimony is easily available. It's searchable, findable, gatherable, navigable, arrange-able, distribute-able, and 
display-able. Such effortless-ness in the Brave New World of The -Able perturbs me because of the extent to which genealogy sites and their archiving categories and operations don't simply enable us to access such material but actually produce and determine our understanding of the Shoah. (See Shandler, 2017) ${ }^{\mathrm{ix}}$

(b) They are comforting and empowering. Such self-curating - whether it's on Facebook, Twitter, Snapchat, or in family albums - offers compelling fantasies of cheer and consolation, as well as of self-governance and selfdetermination.

(c) They are rewarding. Like most activities in our leisured consumer capitalist experience economy - which tries to make us feel that 'doing' stuff, and then 'sharing' it, is a replacement rather than merely a refinement of 'buying' stuff - the more we invest the greater our return. Searching for and retrieving, examining, and placing another newly verified piece of evidence in the jigsaw that is our imminently completed family portrait - the false promise of put-backtogether-again-ness - validates further our impulse as armchair genealogists to do research, to search, to be curious, to have our un-fulfil-able will-to-know sated again and again in an endless eternal return of desire, accumulation, and consumption.

(d) They encourage multi-tasking. Curiosity on the Internet is born of a browsing sensibility, as we surf from one memorial site of pilgrimage to the next, wander from one genealogy database to the next, from one document to another, and, effortlessly, wander off to read the Guardian, watch some porn, post on Twitter, and wander back again. While such browsing is no more of less prevalent when searching online genealogy sites than any other websites, it's being distracted from this knowledge's particularity that concerns me. 
(e) It's the most effortless (and thus painless) site-seeing. Shoah pilgrims that are too lazy or can't be bothered to actually go to Poland or wherever can sit at home on our fat arses and do our genealogical research remotely. And the remote-ness that this affords is a blessed relief because it circumvents the material encounter. Online genealogy sites provide no site, sacred or otherwise, and so barely a physical, corporeal, or affective experience. No monuments. No sculptural forms. No gateways or barracks. No crematoriums. No artefacts, no remnants, no belonging. No piles of eyeglasses. No piles of toothbrushes. No piles of children's shoes. No piles of wedding rings. No piles of the ashes of incinerated Jews. No incomprehensibility and thus no need for decipherability. Let's be honest, removed from the actual extermination camps and museums of remembrance, searching online, in the comfort of your own home, is the most wonderfully wilfully sanctioned way to avoid or refuse the demands and challenges of traumatic history, of direct (albeit still proximate) affective experience, and of critical self-reflection. Instead, these sites offer words and images; and for sure we know how to look at images on the Internet, whether they're porn, food porn, property porn, ruin porn, war porn, Shoah porn, whatever.

(f) Online genealogy sites offer words and images and... clicks. In our contemporary épistémè of re-search, in which all knowledge is a capitalized and monetized commodity in our 'knowledge economy', and when information rarely reaches the heady heights of knowledge as such, these sites confirm that when it comes to doing genealogical research, in fact any research, there is an intensification of the degree to which what can be searched for (i.e. content) is now perhaps almost less important than how we can search for it. Rather than 
content, then, it is in these dynamics of searchability, along with the processuality and the operationality of the system (such as archiving software), that value resides. We might try to deny it, but it is true whenever we (i) goggle at the speed of our Internet-related services (ii) delight at the ease with which we find another piece of our genealogical puzzle, and (iii) sit there marvelling that on our screen there's a Page of Testimony for what might be great-great uncle Hersz listing his date of death as 04/03/1943 and his place of death as Ludwigsdorf Camp; or that there's a photograph of a crowded Chmielnik town square on $08 / 10 / 1942$, the day the town was liquidated and almost all of its Jewish inhabitants, about 8,000, were transported to Treblinka's gas chambers. And we want to cry for the dead, for our dead, to remember and commemorate them, to mourn them, to feel the affect, and to observe and care and follow and obey the protocols of mourning rituals and the emotions stirred by them, to have an experience provoked by such an historically vivid, indexical redolent invocation of the dead, of our dead, but all we can say is: 'Wow, that's, like, really moving. I don't know what to say'. And then we click on the next tab...

\section{Conclusion: Resilience}

We hear a bell tinkling.

It's 11.01 on Thursday 25th May 2017.

In the Ashmolean Museum's Education Department, we shake ourselves

from our reverie. Our students have observed the minute's silence immaculately. I can tell that they've observed, they've cared, they've followed and obeyed. So 
have I. Our study day in Oxford continues; life is forever changed, and forever the same.

That evening, I'll speak with my daughter about her minute's silence at school, and she'll tell me that she can't remember what her teacher said to her and her classmates, nor can she remember what she did, nor what she thought. My daughter is five and three quarters, and has the short-term memory of a gold fish. The following week I will speak with my daughter's teacher who says that the School's Head - having sought guidance from colleagues, the School's governors, and heads of other schools - marked this grievable moment by speaking with the children collectively in a 'child appropriate manner'.

I began writing this article a week or so after the minute's silence on Thursday 25th May 2017. From Monday 22nd May 2017, the day of the terrorist bomb attack at the Ariana Grande concert in Manchester, until 21 $1^{\text {st }}$ September 2017, the day I submitted it for consideration to Journal of Visual Culture, the death toll in England from terrorist-related murder stands at 35. In this finite timeframe, an inventory of terrorist-related murders, and major and minor incidents relating to them, could be logged thus:

\subsection{British Standard Time (BST), Monday 22 $2^{\text {nd }}$ May 2017, Salman Ramadan} Abedi detonates a bomb at an Ariana Grande concert in Manchester Arena, murdering 22 adults and children. (His death by suicide makes it 23.)

11.00 BST, Thursday 25th May 2017, a minute's silence is observed for those murdered in Manchester.

11.01 BST, Thursday 25th May 2017, after the minute's silence ends in Manchester's St Ann's Square, a woman in the crowd begins to singing 'Don't 
Look Back in Anger' by Oasis. Others assembled join her. It isn't everyone, as media reports suggest, but it's a significant number raising their voices in solidarity. It might be what Judith Butler would call a performative action. (Butler, 2015, passim)

22.07 BST, Saturday $3^{\text {rd }}$ June 2017, ambulances are called in response to a white van being driven purposefully into pedestrians on London Bridge. After the van crashes, three men run to close-by Borough Market where they stab people sitting outside cafes, bars, and restaurants with long knives. Seven people are known to have been murdered.

04.43, Sunday $4^{\text {th }}$ June 2017, the $45^{\text {th }}$ President of the United States of America tweets:

Donald J. Trump

@realDonaldTrump

Follow

Do you notice we are not having a gun debate right now? That's because they used knives and a truck!

4:43 AM - 4 Jun 2017

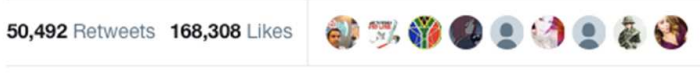

Trump's tweet is 'liked' 168,308 times. (Fig. 7)

Sunday $4^{\text {th }}$ June 2017, Ariana Grande stages the One Love concert in Manchester to benefit those affected by the bomb attack on Monday $22^{\text {nd }}$ May. Monday $5^{\text {th }}$ June, Islamic State claim responsibility for Saturday's attack. 
11.00 BST, Tuesday $6^{\text {th }}$ June 2017 , a minute's silence is observed for those who lost their lives and were affected by the attacks on London Bridge/Borough Market.

Tuesday $6^{\text {th }}$ June 2017, a body is recovered from the Thames at Limehouse. It is confirmed that it is the eighth victim of the incident on $3^{\text {rd }}$ June. It is thought that he was hit by the white van, and thrown off London Bridge into the water.

Thursday $8^{\text {th }}$ June 2017, all but one of Saudi Arabia's national football team fail to observe a minute's silence held before a World Cup qualifier against the Australian national football team at Adelaide Oval in tribute to the two Australians killed in the terrorist attack in London on $3^{\text {rd }}$ June. This is a decision, it seems, made by the Saudi Arabian Football Federation. It turns out that 'a minute's silence [is] not a recognised way to show respect and condolences in [Saudi Arabia's] culture or in Islam more broadly'.x On Friday 9th June, the Federation make an 'unreserved' apology, and announce that it 'condemns all acts of terrorism and extremism and extends its sincerest condolences to the families of all the victims and to the government and people of the United Kingdom.' Final score: Australia 3, Saudi Arabia 2. $14^{\text {th }}$ June 2017 , it is announced that Manchester city council will make Ariana Grande an honorary citizen of the city.

00.20 BST, Monday 19th June 2017, a white van, rented in Cardiff, Wales, four days earlier is driven into a crowd of worshippers leaving Ramadan prayers at a community centre in Finsbury Park, north London, killing one and injuring nine others. Witnesses report that the driver shouted: 'I want to kill all Muslims'. 
A 47-year-old man, Darren Osborne, has been charged with terrorist-related murder and attempted murder, but is yet to stand trial.

0.5.12, Monday 19th June 2017, white supremacists in the US celebrate this murder, declaring that there may still be 'hope for the British'. (Fig. 8)

On the evening of Friday 23 ${ }^{\text {rd }}$ June 2017, Noel Gallagher, formerly of Oasis, performs 'Don't Look Back in Anger' at Glastonbury.

Around 18.40 BST, Saturday 24th June 2017, Liam Gallagher, formerly of Oasis, performs 'Don't Look Back in Anger' at Glastonbury, dedicating it to those who lost their lives in the Manchester terror attack, the London terror attack, and the fire at Grenfell Tower, a West London residential tower block.

12.00 BST, $2^{\text {th }}$ June 2017, a minute's silence is observed in remembrance of those affected by the terrorist attack in Finsbury Park.

11.30 BST, $7^{\text {th }}$ July 2017, a minute's silence is observed to remember the 52 people killed in London on $7^{\text {th }}$ July 2007 when four suicide bombers detonated devices across the transport network. 
I must admit, I don't understand why ‘Don't Look Back in Anger' by Oasis would be the song to suit the situation, to provoke, galvanise, or rally performative action.

What does the song mean? Don't dwell in the past, look to the future? You have to work through the past in order to move on? Just move on? We forgive you? We will carry on? 'We won't let hate win', said Ariana Grande, and it's glib, but its sentiment is consistent with the vox populi. Charlotte Campbell, at a vigil for her daughter, Olivia, aged 15, murdered in the terrorist attack at Manchester Arena, implored the assembled crowd: 'Please stay together, don't let this beat any of us. Please. Don't let my daughter be a victim'. But it has, and she is.

Perhaps there is a better question: what do these performative actions $d o$ ? Such congregating are poignant acts of solidarity, of community in the face of adversity, whether in Manchester or London or Barcelona or Berlin or Stockholm or Turku, or Charlottesville. It's not so much that the song per se becomes an unofficial anthem of defiance and resilience, but that its singing as defiance and resilience demonstrates the rights of the individual to assemble. As an event, a grievable moment, of conjuncture between the structure of our quotidian existence (our rituals and conventions, and their operations) and the contingency afforded by the minute's silence, as I referred to it earlier, such rights are exercised by individuals on their own behalf, on behalf of one another, and their city, as citizens of this broken country. Like memorials as structures-toremind-us that carry with them an a priori knowledge that they are insufficient, so an exercising, an articulation, a statement (at a vigil, as a memorial), such an operative performative action becomes an affirmative site, a site of affirmation, 
an utterance around which remembering can congregate and the process of memory-telling can begin. (Simply, the act of stating or uttering or singing shatters perhaps irreparably and strikingly the silence, and what it stands for, ushering in a new patterning for observance.) Such public action, these acts of political self-determination, enact those rights. They are acts of symbolic defiance, of defiance and resilience, of collective determination - despite or perhaps because of the carnage, the trauma, the Nachträglichkeit, Brexit, ten years of austerity, precarity, and so on and so forth. Demonstrating coming together-ness - solidarity and diversity, solidarity in diversity, solidarity as diversity, diversity as solidarity - is what observance as a grievable moment has the capacity to do.

Such acts fill me with awe and wonder; and not a little jealousy. I am so filled with admiration for a human being's capacity, let's say Charlotte Campbell's capacity - let's add Susan Bro, the mother of murdered anti-fascist protester Heather Heyer, at her daughter's memorial service - to be brave and outraged and undaunted. (Susan Bro urged the crowd to honor the memory of her daughter by channeling 'anger into righteous action'.) That Campbell, that Bro, that we have the capacity, the... humanity... to be sympathetic, empathetic, compassionate, defiant, angry, to effectuate numerous spontaneous acts of kindness and heroism, right in the midst of such a grievable moment. To be resilient. The greater the evil, the stronger the good becomes; I don't know how to think in terms of good and evil, but they do, and they are unerring. All I can do is be inspired by (as well as sceptical of) these acts, try to be better and do better myself, and mark such performative action, for good and ill, 
by way of this article as a testament to both the engendering as well as the ungracious character of us as human, all too human.

In British national life, for almost 100 years, since the first anniversary of the Armistice on November $11^{\text {th }}, 1919$, we have been using commemorative durational silences as a secular, vernacular ritual of observance associated with remembering the dead. While such a praxis may obliquely carry the unacknowledged residue of the Quakers' silent worship, and before them of observing and remembering the Sabbath for Christians and Jews, it strikes me that in the contemporaneity of our Memory Industry such observance as a performative action evokes planetarity and is thus more considerable than mere religion.

There will be no let up in this need for observance: the need to assemble; to come together as a nation (which is not a time for nationalism); to pay attention and care, follow, obey, to observe and to be seen to be observing; the need to need to mourn, to remember, and to commemorate the dead.

And let's be reminded that etymology is clear, as I wrote towards the beginning of this article, that observance is not observing per se but the act of observing and paying attention and caring, not following per se but the act of following a particular custom, not obeying per se but an action performed in accordance with a ritual. Observance as a grievable moment turns it into what it always and already is: it turns observing, caring, following, obeying into action, into acts - often into righteous action - of reciprocal obligation to others. 
To remember the dead is to mark them. This function has frequently been served by 'the list' as a trope or form or operation, with increased regularity since the emergence of an earlier iteration of the Memory Industry's archival impulse. The list was adopted early in memorials to the Shoah, having been utilised already in 1946 to commemorate the dead by way of a memorial inscription on the chimney of the Flossenbürg crematorium. Its frequency (the 'wall of names' model for instance) encompasses the monumentality of the Vietnam Veterans Memorial in Washington DC (Maya Lin, dedicated in 1982) and the more modest wall of names in the synagogue in Chmielnik, the Polish town of two of my greatgrandparents, which because of the long-derelict synagogue's restoration in 2013 is now a regular stop on the shtetl route.

To list the dead, often to mark the unmarked, is also to begin the task of re-membering the destroyed synagogues, the razed cemeteries, the broken headstones. For the list serves a referential function (it is historical, informational, instrumental, returning the dead their names), whilst at the same time serving a metaphoric or symbolic function (remembering, commemorating, marking itself). As a mnemonic device, its function as memorial is then both indexical and metaphorical, an enumeration and an articulation. It is specific and generalizable, individualised and collectivist, finite and endless. Anxiety-inducing and a calming balm. It is filled with painfully personal details and (banally, sublimely, horrifically) repetitive ad infinitum, as are the facts in and that constitute any and every listing.

To end this article it seems fitting, then, to take as my guide the ultimate list or listing paradigm: the Page of Testimony from The Central Database of Shoah Victims' Names at Yad Vashem. As is well known, Yad Vashem was 
established in 1953 as Israel's official national memorial authority and institution to the victims of the Holocaust, and now describes itself as the 'World Holocaust Remembrance Centre' and 'the Jewish people's living memorial to the Holocaust'. The listing format for its Pages of Testimony (first name, surname, born date, son of, born in, married to, profession, residence, date of death, place of death) is tried and tested. It is perhaps because of Yad Vashem that the Page of Testimony is now the ur-form of commemoration, and the privileged form for truth telling, for preserving memory.

What is perhaps less well known (but should come as no surprise) is that Yad Vashem is also, according to Wikipedia, the second-most-visited Israeli tourist site, so, given this article's concerns, it seems somewhat fitting, and hopefully not too indecorous, not too much of a 'Holocaust effect', to adapt and re-purpose this format for a non-Shoah-related, in fact not-at-all-Jewish performative action of secular, vernacular observance.

One final thought: given that listings are seemingly endless, and can thus so easily dissolve individualised referentiality into a transcendental symbolic memento mori, it's a righteous action to read them painstakingly.

\author{
Abedi, Salman Ramadan, 22, from Manchester, killed by his own homemade \\ bomb, Manchester Arena, Manchester, 22 $2^{\text {nd }}$ May 2017.
}

\begin{abstract}
Ali, Makram, 51, born Bangladesh, lived in Haringey, North London, struck by a white van and died of multiple injuries, Seven Sisters Road, Finsbury Park, Monday 19th June, 2017, murdered by Darren Osborne.
\end{abstract}


Archibald, Christine, 30, from Castlegar, British Columbia, struck by a white van driven into pedestrians by terrorists, died in her fiancé's arms on London Bridge, murdered by Khuram Shazad Butt, Rachid Redouane, and Youssef Zaghba on Saturday $3^{\text {rd }}$ June 2017.

Atkinson, John, 28, from Radcliffe, Greater Manchester, support worker, murdered in terrorist attack carried out by Salman Ramadan Abedi at Manchester Arena, Manchester on Monday 22nd May 2017.

Bélanger, Sébastien, 36, from Angers, French, chef, stabbed to death at Borough Market, murdered by Khuram Shazad Butt, Rachid Redouane, and Youssef Zaghba on Saturday $3^{\text {rd }}$ June 2017.

Boden, Kirsty, 28, from Loxton, South Australia, stabbed in the chest while coming to the aid of the injured at Borough Market, murdered by Khuram Shazad Butt, Rachid Redouane, and Youssef Zaghba on Saturday $3^{\text {rd }}$ June 2017.

Boyle, Courtney, 19, from Gateshead, student at Leeds Beckett University, waiting to collect her younger sister Nicole, murdered in terrorist attack carried out by Salman Ramadan Abedi at Manchester Arena, Manchester, on Monday 22nd May 2017.

Brewster, Kelly, 32, from Sheffield, civil servant, died shielding her niece from the blast, murdered in terrorist attack carried out by Salman Ramadan Abedi at Manchester Arena, Manchester on Monday 22nd May 2017. 


\begin{abstract}
Butt, Khuram Shazad, 27, British citizen, born in Pakistan, former London Underground worker, shot dead by police marksmen in Borough Market by 22.16 BST on Saturday 3rd June 2017.
\end{abstract}
Callander, Georgina, 18, from Chorley, Lancashire, student at Runshaw College, murdered in terrorist attack carried out by Salman Ramadan Abedi at Manchester Arena, Manchester on Monday 22nd May 2017.
Campbell, Olivia, 15, from Bury, Greater Manchester, pupil at Tottington High School, murdered in terrorist attack carried out by Salman Ramadan Abedi at Manchester Arena, Manchester on Monday 22 ${ }^{\text {nd }}$ May 2017.
Curry, Liam, 19, from South Shields, student at Northumbria University, murdered in terrorist attack carried out by Salman Ramadan Abedi at Manchester Arena, Manchester on Monday 22 ${ }^{\text {nd }}$ May 2017.
Echeverría, Ignacio, 39, from Las Rozas, Spain, worked in money laundering prevention at $\mathrm{HSBC}$, died in Borough Market trying to defend a woman who was being stabbed, murdered by Khuram Shazad Butt, Rachid Redouane, and Youssef Zaghba on Saturday $3^{\text {rd }}$ June 2017.
Fawell, Wendy, 50, from Otley, West Yorkshire, former primary school worker, murdered in terrorist attack carried out by Salman Ramadan Abedi at Manchester Arena, Manchester on Monday 22nd May 2017.


Hett, Martyn, 29, from Stockport, PR manager, murdered in terrorist attack carried out by Salman Ramadan Abedi at Manchester Arena, Manchester on Monday 22nd May 2017.

Howe, Alison, 45, from Royton, Oldham, waiting to pick up her daughter, murdered in terrorist attack carried out by Salman Ramadan Abedi at Manchester Arena, Manchester on Monday 22nd May 2017.

Hurley, Megan, 15, from Halewood, near Liverpool, pupil at Halewood Academy, murdered in terrorist attack carried out by Salman Ramadan Abedi at Manchester Arena, Manchester on Monday 22 ${ }^{\text {nd }}$ May 2017.

Jones, Nell, 14, from Goostrey in Cheshire, pupil at Holmes Chapel Comprehensive School, murdered in terrorist attack carried out by Salman Ramadan Abedi at Manchester Arena, Manchester on Monday 22nd May 2017.

Kiss, Michelle, 45, from Whalley, Lancashire, waiting to pick up her daughter, murdered in terrorist attack carried out by Salman Ramadan Abedi at Manchester Arena, Manchester on Monday 22 ${ }^{\text {nd }}$ May 2017.

Klis, Angelika, 40, from Poland, lived in York, waiting to pick up her two children, murdered in terrorist attack carried out by Salman Ramadan Abedi at Manchester Arena, Manchester on Monday 22 ${ }^{\text {nd }}$ May 2017. 
Klis, Marcin, 42, from Poland, lived in York, cabdriver, waiting to pick up his two children, murdered in terrorist attack carried out by Salman Ramadan Abedi at Manchester Arena, Manchester on Monday 22nd May 2017.

Leczkowski, Sorrell, 14, lived in Adel in Leeds, pupil at Allerton High School, Leeds, murdered in terrorist attack carried out by Salman Ramadan Abedi at Manchester Arena, Manchester on Monday 22nd May 2017.

Lees, Lisa, 47, from Royton, Oldham, waiting to pick up her daughter, murdered in terrorist attack carried out by Salman Ramadan Abedi at Manchester Arena, Manchester on Monday 22nd May 2017.

MacLeod, Eilidh, 14, from the Isle of Barra, Outer Hebrides, pupil at Castlebay Community School, murdered in terrorist attack carried out by Salman Ramadan Abedi at Manchester Arena, Manchester on Monday 22nd May 2017.

McIver, Elaine, 43, from Ellesmere Port, Cheshire, police officer, waiting to pick up her step-daughter, murdered in terrorist attack carried out by Salman Ramadan Abedi at Manchester Arena, Manchester on Monday 22nd May 2017.

McMullan, James, 32, from Hackney, east London, web entrepreneur, stabbed to death on Borough High Street, murdered by Khuram Shazad Butt, Rachid Redouane, and Youssef Zaghba on Saturday $3^{\text {rd }}$ June 2017. 
Pigeard, Alexandre, 26 or 27, from Caen or Colleville-Montgomery, Normandy, waiter at Boro Bistro, stabbed in the neck, murdered by Khuram Shazad Butt, Rachid Redouane, and Youssef Zaghba on Saturday 3rd June 2017.

Redouane, Rachid (aka Rachid Elkhdar), 30, Irish identity, claimed to be Moroccan and Libyan, pastry chef, shot dead by police marksmen in Borough Market by 22.16 BST on Saturday $3^{\text {rd }}$ June 2017.

Roussos, Saffie Rose, 8, from Tarleton, near Preston in Lancashire, pupil at Tarleton Community Primary School, murdered in terrorist attack carried out by Salman Ramadan Abedi at Manchester Arena, Manchester on Monday 22 ${ }^{\text {nd }}$ May 2017.

Rutherford, Chloe, 17, from South Shields, student and part time travel agent, murdered in terrorist attack carried out by Salman Ramadan Abedi at Manchester Arena, Manchester on Monday 22nd May 2017.

Thomas, Xavier, 45, French national, business and events and travel manager, mowed down by terrorists' van on London Bridge and thrown into the Thames, death by immersion, murdered by Khuram Shazad Butt, Rachid Redouane, and Youssef Zaghba on Saturday $3^{\text {rd }}$ June 2017.

Tron, Philip, 32, from Gateshead, waiting to pick up his step-daughter Nicole Boyle, murdered in terrorist attack carried out by Salman Ramadan Abedi at Manchester Arena, Manchester on Monday 22nd May 2017. 
Tweddle-Taylor, Jane, 51, from Blackpool, receptionist, murdered in terrorist attack carried out by Salman Ramadan Abedi at Manchester Arena, Manchester on Monday 22nd May 2017.

Zaghba, Youssef, 22, Italian national, born in Fes, Morocco, lived in east London, development coach at children's gymnastics club, shot dead by police marksmen in Borough Market by 22.16 BST on Saturday $3^{\text {rd }}$ June 2017

Zelenak, Sara, aged 21, Australian national, born in Brisbane, lived in London, nanny/au pair, stabbed to death in Borough Market, murdered by Khuram Shazad Butt, Rachid Redouane, and Youssef Zaghba on Saturday 3rd June 2017.

\section{References}

Adorno TW $(1997[1983,1981,1967,1951)$ Cultural Criticism and Society', Prisms, trans. Samuel and Shierry Weber, Cambridge: The MIT Press: 17-34, p. 34.

Agamben G (2007) Infancy and History: On the Destruction of Experience, trans. Liz Heron. London Verso. 
Antick P (2007) itourist? Journeys through the Holocaust. Southampton: John Hansard Gallery.

Bal M (1999) Quoting Caravaggio: Contemporary Art, Preposterous History. Chicago: The University of Chicago Press.

Bruno G (2014) Surface: Matters of Aesthetics, Materiality, and Media. Chicago: University of Chicago Press.

Butler J (2015) Notes Toward a Performative Theory of Assembly. Cambridge: Harvard University Press.

Chan P (2010) 'A Time Apart', in Klaus Biesenbach, Cornelia H. Butler, and Neville Wakefield (eds) Greater New York, New York: MoMA PS1 and the Museum of Modern Art, 84-5.

(http://altcomics.tumblr.com/image/143019333856)

Crary J (2014) 24/7: Late Capitalism and the Ends of Sleep. London: Verso.

Farocki H (2004) 'Phantom Images', Public 29, 12-22, p. 17

Friedländer S (1997[1988]) Nazi Germany and the Jews: The Years of Persecution, 1933-39. London: Orion Books Ltd.

Hilberg R (1961) The Destruction of European Jews. London: W. H. Allen. 
Klein, KL (2000) On the Emergence of Memory in Historical Discourse. Representations, 69. Winter 2000, 127-150.

LaCapra D (1994) Representing the Holocaust: History, Theory, Trauma. Ithaca: Cornell University Press.

Lanzmann C. (1995) 'The Obscenity of Understanding: An Evening with Claude Lanzmann', in Trauma: Explorations in Memory, eds. Caruth C. and David Rodowick, Baltimore: Johns Hopkins University Press, 200-220.

Oxford English Dictionary

Levi P (2003[1986]) The Drowned and the Saved.trans. Raymond Rosenthal. London: Abacus.

Moshenska G (2015) Curated Ruins and the Endurance of Conflict Heritage. Conservation and Management of Archaeological Sites, 17:1, 77-90.

Osborne P (2013) ANYWHERE OR NOT AT ALL: Philosophy of Contemporary Art. London: Verso.

Ross C (2012) The Past is the Present: It's the Future Too: The Temporal Turn in Contemporary Art. London: Bloomsbury. 
Serres M with Bruno Latour (1995[1990]) Conversations on Science, Culture, and Time, trans. Roanne Lapidus, Ann Arbor: The University of Michigan Press.

Shandler J (2017) Holocaust Memory in the Digital Age: Survivors' Stories and New Media Practices. Stanford: Stanford University Press.

Smith M (2013) Theses on the Philosophy of History: The Work of Research in the Age of Digital Searchability and Distributability. Journal of Visual Culture, Vol 12(3): 375-403.

Spivak GC (2003) Death of a Discipline. New York: Columbia University Press.

van Alphen E (1997) Caught by History: Holocaust Effects in Contemporary Art, Literature, and Theory. Stanford: Stanford University Press.

van Alphen E (2015) List Mania in Holocaust Commemoration, in Tanja Schult and Diana I. Popescu (eds.) Revisiting Holocaust Representation in the PostWitness Era, London: Palgrave, 11-27.

Young JE. (1993) The Texture of Memory: Holocaust Memorials and Meaning, New Haven: Yale University Press.

Young JE (1994) (ed) The Art of Memory: Holocaust Memorials in History. PrestelVerlag, New York. 


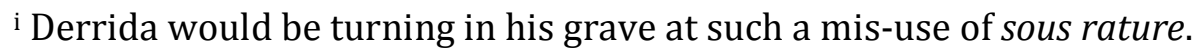

ii This article is a 'working through' of the ideas that conceptually underpin and over-arch that chapter as it's being researched, and coming to be written. It's an effort to get myself un-stuck.

iii For an account of the emergence of the Memory Industry in an earlier iteration see Klein, 2000.

iv Here I allude to Elie Wiesel, and also George Steiner.

$\mathrm{v}$ It turns out that iconomachy is a double bind too: the performative action of the destruction of images and objects and forms is, in turn, a proem to performative action.

vi Now a ubiquitous global phenomenon, dark tourism has been documented as such for around 150 years, from Mark Twain's Innocents Abroad in which Twain writes about the exploiting of the past for profit, and dedicates a chapter to Pompeii, to Anton Chekhov, the original 'gulag tourist', and beyond.

vii See also the controversy at 2017's documenta14 around Franco 'Bifo' Berardi's 'Auschwitz on the Beach' performance, and the discussion on the controversy here: http://www.documenta14.de/en/calendar/24356/shame-on-us-a$\underline{\text { reading-and-discussion }}$

viii This thinking emerges from somewhere between Baudrillard's interpretation in In the Shadow of the Silence Majorities (1978) of the passivity/docility/nonparticipation/indifference of 'the masses' as an active refusal of (a 'collective retaliation' against) society's recommended ideals; and Hardt and Negri's 
considerations of the refusal/failure of 'the multitude' to enter into a social contract with a sovereign political body as sketched in Empire (2000) and Multitude (2004).

ix Note that I'm not of course advocating that a web-based search for and access to material relating to the Shoah should be any different in terms of speed and efficiency to any other kind of search, but simply pointing out that the absence of a discernable difference, operationally, between them and any and all information on the Internet leads to a flattening out of the knowledge/content therein.

x https://www.theguardian.com/football/2017/jun/08/saudi-arabiafootballers-ignore-minutes-silence-for-london-attack-victims (accessed $9^{\text {th }}$ June 2017) 